\title{
UDC 629.463.027.2-028.77
}

\author{
S. V. MYAMLIN ${ }^{1}$, O. O. TEN ${ }^{2}$, L. O. NEDUZHA ${ }^{3 *}$ \\ ${ }^{1 *}$ Dep. «Cars and Car Facilities», Dnipropetrovsk National University of Railway Transport named after Academician \\ V. Lazaryan, Lazaryan St. 2, Dnipropetrovsk, Ukraine, 49010, tel./fax +38 (056) 793 19 03, e-mail sergeymyamlin@gmail.com, \\ ORCID 0000-0002-7383-9304 \\ ${ }^{2}$ CJSC «Promtraktor-Vagon», Ilich St., 1 a, Kanash, Chuvash Republic, Russian Federation, 429332 \\ ${ }^{3 *}$ Dep. «Striuctural Mechanics», Dnipropetrovsk National University of Railway Transport named after Academician \\ V. Lazaryan, Lazaryan St., 2, Dnipropetrovsk, Ukraine, 49010, tel./fax +38 (056) 793 19 03, e-mail nlorhen@i.ua, \\ ORCID 0000-0002-7038-3006
}

\section{EXPERIMENTAL RESEARCH OF DYNAMIC QUALITIES OF FREIGHT CARS WITH BOGIES OF DIFFERENT DESIGNS}

Purpose. With the advent of new designs of freright cars the task of designing the more modern bogies, assessment of their dynamic properties depending on the type and structure of pecularities, accounting the axle loadings, providing the dynamic and running characteristics, meeting the conditions of impact on the track, stability, and frame forces intensity etc. becomes especially important. In order to launch the new production into manufacture and to assess the dynamic properties using different designs of bogies the running testes were conducted. They allowed one to compare the dynamic performance of the new bogie with the existing models. Methodology. The study was conducted using the method of numerical integration and mathematical modeling of dynamic loading of freight cars using the software package «Dynamics of Rail Vehicles» («DYNRAIL»). Findings. The results of studies of dynamic characteristics of open cars with new and worn wheels of bogie models 18-9771, 18-9770 and 18-578 in graphical and tabular form are presented. All figures are within the normative values and do not exceed the maximum admissible ones. Originality. When designing the bogie for loading $23.5 \mathrm{t} / \mathrm{axle}$ almost all available technical solutions to improve the characteristics of the freight car bogies (elastic bearers, cassette bearing in axle boxes, axle boxe adapter of original design, bilinear central spring suspension, etc.) were used. Practical value. As a result of the engineering works on projecting and manufacturing of the improved designs of freight car bogies a new design was received. It is highly competitive with the dynamic qualities of the best ones. Made choice of rational values of elastic-dissipative parameters of the bogie allows one to create standard series of running gears for freight cars for promising operating conditions. The results are of practical importance. They have found reflection in the number of author's publications in special and semi-popular editions.

Keywords: freight cars; bogie bearers; traffic speed; tangent and curved track sections; dynamic performance

\section{Introduction}

The main criteria for assessment of dynamic qualities of rail vehicles that determine the operation mode of rolling stock, as we know, are its dynamic indicators. They should take into account current trends of modern freight car building $[13,15,17]$ and correspond to the regulatory documents $[12,8]$. With the advent of new designs of freright cars the task of designing the more modern bogies, assessment of their dynamic properties depending on the type and structure of pecularities, accounting the axle loadings, providing the dynamic and running characteristics, meeting the conditions of impact on the track, stability, and frame forces intensity etc. becomes especially important $[5,6]$. At the same time the bogie should be universal, interchangeable with the bogies existing in operation according to installation dimensions and standardized to the maximum level according to the components. It should be not only simple in design, but also in manufacturing (to ensure minimum production costs and technical maintenance of such bogies). Their operation should be costeffective.

\section{Purpose}

In order to launch the new product into manufacture and to assess the dynamic properties using different designs of bogies the running testes were conducted. They allowed one to compare the dynamic performance (coefficient of vertical dynamics of the body frame, coefficient of vertical dynamics of unsprung bogie, the ratio of side frame force to the static axial loading, derailment stability coefficient) of the new bogie with the existing models. 


\section{Methodology}

In order to verificate the design decisions previously the theoretical studies for determination the dynamic loading of cars with bogies 18-100 (as a standard), Y25, 18-9771 were carried out [7, 9]. The mathematical model and DYNRAIL software developed in Dnipropetrovsk National University of Railway Transport named after Academician V. Lazaryan were used during the theoretical studies $[18,19]$. Simulation was carried out throughout the range of operating speeds of freight cars on tangent and curved track sections by varying the parameters of elastic elements of the bogie spring suspension, elasticity in bearers and axle box. Rail irregularities were set as the numerical implementations, which had the statistical characteristics similar to real track irregularities. Also, it was possible to set the track irregularities in accordance with current regulatory documentation.

Analysis of the results of theoretical studies made it possible to conclude that for all bogie models the dynamic values of quality indicators for open cars differed within the requirements of regulatory documents $[2,8]$ and did not exceed the maximum permissible values. These indicators are the coefficient of horizontal dynamics of unsprung part of the car $C \mathrm{dh}$ and the coefficient of vertical dynamics of the unspung part of the car $C \mathrm{dv}$, the stability coefficient of the wheel climbing on the rail $C$ s. The values of $C \mathrm{dv}$ and $C \mathrm{dh}$ on the straight track section at the design speed of $120 \mathrm{~km} / \mathrm{h}$ indicated that the bogie model 18-9771 as compared to the models 18-100 and Y25 according to dynamic performance turned out to be better, although it is designed for axle loading $23.5 \mathrm{tnf}$.

According to results of performed experimental studies the influence of different bogie designs on the basic dynamic indicators of traffic safety of freight cars in the empty and loaded modes. In this case of four-axle open cars coefficient dynamics these indicators are: the vertical dynamics coefficient of the body frame $(\mathrm{Cd})$, the coefficient of vertical dynamics of unsprung bogie frame $(C \mathrm{du})$, the ratio of the side frame force to the static axial loading $(H \mathrm{p} / P \mathrm{O})$, the derailment stability coefficient $(C \mathrm{~s})$.

\section{Basic material.}

In order to launch the new production into manufacture and to assess the dynamic qualities using the different bogie designs on the speed test ground of OJSC «VNIIZhT» (Belorechenskaya Station, North Caucasian railway, Russian Federation) the running tests were carried out. They allowed comparing the dynamic performance of the new bogie model 18-9771 (Fig. 1, a) with bogie models 18-9770 (Fig. 1, b) and 18-578 (Fig. 1, c).

Both, the cars with new bogies and the cars with the maximum worn ones but allowed to operation were tested. The tests were carried out in the volumes necessary to launch new production into manufacture.

\section{Description of the test objects.}

Bogie model 18-9771 is a development of CJSC «Promtractor-Vagon» (Republic of Chuvashia, Canas, Russian Federation) with increased run life 500 thous. $\mathrm{km}[9,10,15,11]$. The bogie has three-element non-rigid frame, protection of friction pairs in pedestal jaw opening and spring opening. Static deflection of the springs of spring group increased to $68 \mathrm{~mm}$ reduces the dynamic impact of car on the track (Table 1).

Application of removable wear resistant elements in friction joints should enhance the stability of rolling stock motion and reduce the costs for maintenance and repair of the running gears. A new developed design for two-axle bogie of freight cars has some differences from other producers and lies in the following:

- side frames and bolsters of strengthened design are made in the form of cast steel using the vacuum-film technology;

- the springs of central spring suspension are made using the height determined by the value of calculated static deflection of central spring suspension under the weight of car and maximum permissible load of the car;

- constant contact bearers of elastic type are set clearance-free;

- wear resistant elements of friction wedges are made of polyurethane, in the friction joint are the wedge-plate, center pad, jaw opening.

The bogie model 18-9770 is designed for the cars of mainline railways with $1520 \mathrm{~mm}$ of rail gage, as well as for the cars of industrial transport $[4,15,13,16,14]$. The bogie is an analogue of the serial bogie model 18-100 (Table 1), but with more advanced technology of cast parts manufacturing side frames, bolsters. 
$a$

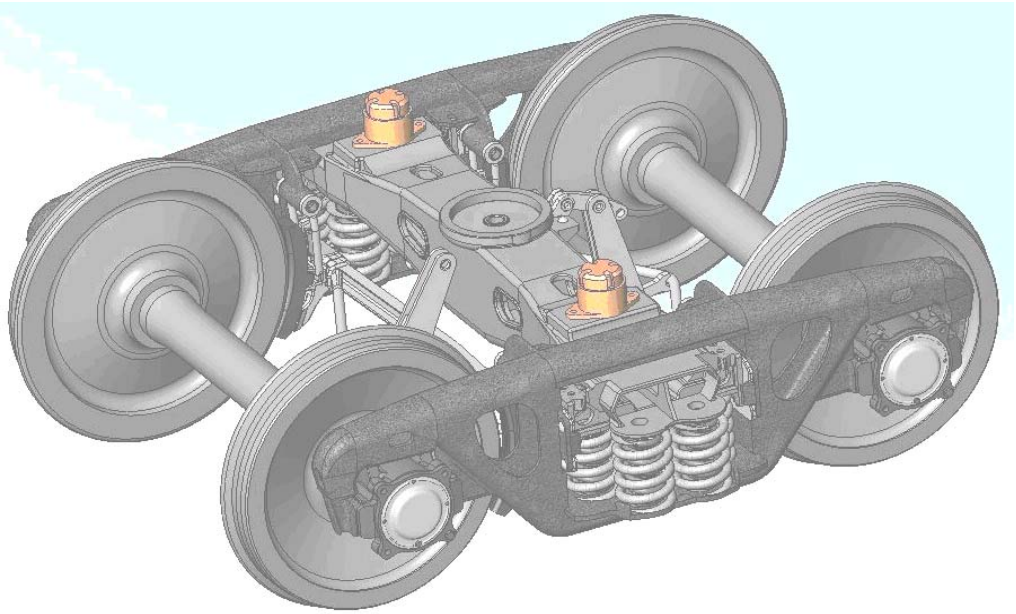

$b$

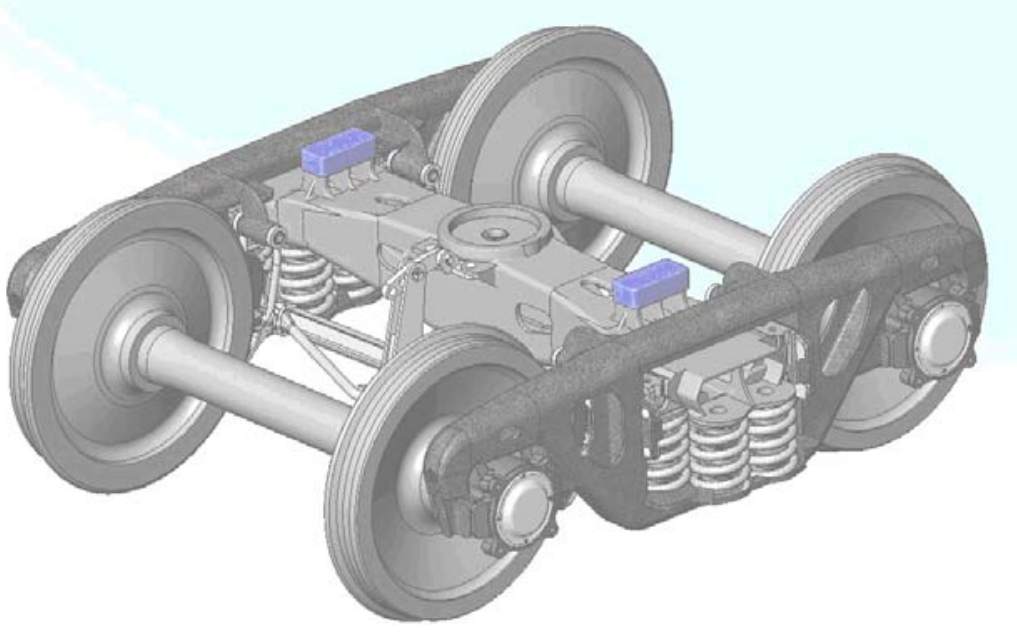

C

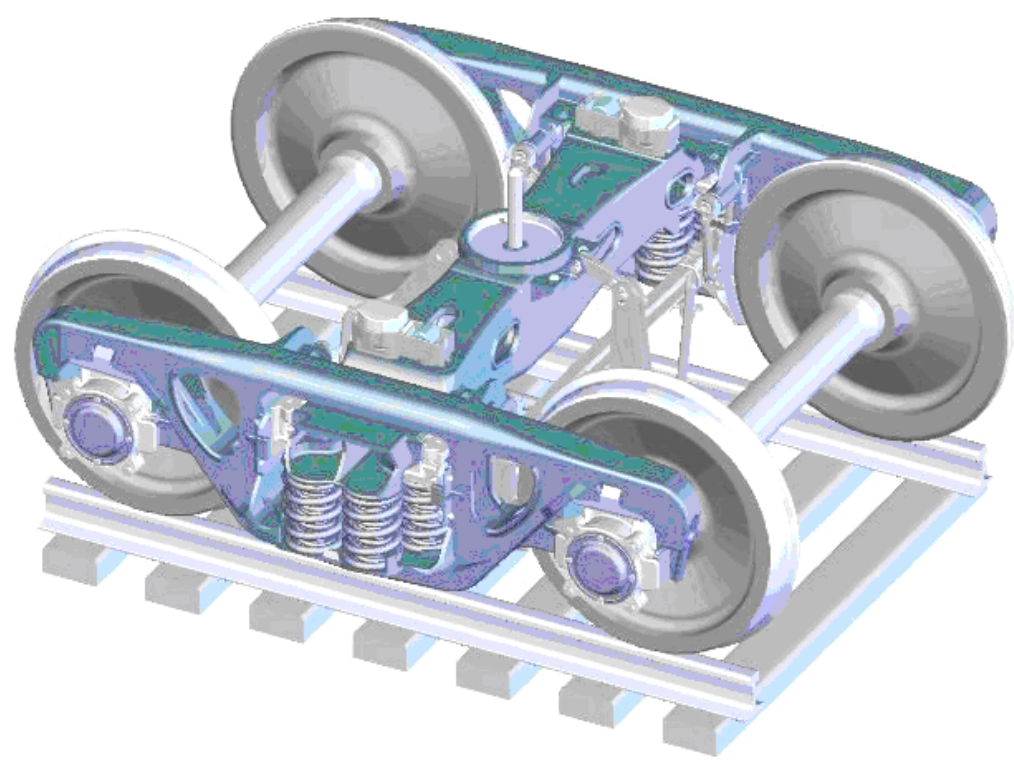

Fig. 1. General view:

$a$ - bogies of the model 18-9771; $b$ - bogies of the model $18-9770 ; c$ - bogies of the model 18-578

(C) S. V. Myamlin, O. O. Ten, L. O. Neduzha, 2014 
The bogie 18-578 (Fig. 1, c) with the loading 23.5 tnf from the axis on the rails [14] is developed by FSUE «Uralvagonzavod». It has a three-element frame of cast structural parts, in the jaw openings of which there are removable wear resistant plates of polyurethane elastomer with mechanical fastening.

The central spring suspension of the bogie is made traditionally. It consists of the set of springs and friction wedge oscillation dampers $[4,13,15]$. The spring set has a linear vertical power characteristics providing the deflection under the weight of loaded car increased to $68 \mathrm{~mm}$, minimum deflection under the weight of the empty car is $13 \mathrm{~mm}$ (Table 1). Elastic friction wedges replace the friction wedges of the bogie 18-100 and completely exclude adhesion of the wedges and bolster wear. The friction plate is the composite one: its main body is $10 \mathrm{~mm}$ thickness and its contact body is $6.5 \mathrm{~mm}$ thickness. New design of the elements in the oscillation damping system in spring suspension of the bogie 18-578 prolongs their service life. At this the wear protection of the inclined surfaces of bolster is ensured, and the main wear occurs on the surface of a replaceable contact plate. Elastic coupling of the wedges with the bolster eliminates the «metal to metal» contact. The elastic-roller bearers of the constant contact with the specified i.e. set rigidity are applied in the bogie.

\section{Findings}

The graphs below show the research results of the dynamic characteristics of cars with bogies of the designs under study:

- vertical dynamics coefficient of unsprung bogie frame $C \mathrm{du}$ and the ratio of the side frame force to the static axial loading $\left(H \mathrm{p} / P_{\mathrm{o}}\right)$ in the straight track sections (Fig. 2, $a-b$ ) and the ratio of the side frame force to the static axial loading $(H \mathrm{p} / \mathrm{Po})$ in the curve with radius $500 \mathrm{~m}$ (Fig. 2, c) in the empty mode;

- vertical dynamics coefficient of the body frame $(C d)$, vertical dynamics coefficient of unsprung bogie frame $(C \mathrm{du})$, the ratio of the side frame force to the static axial loading $(\mathrm{Hp} / \mathrm{Po})$ in the straight (Fig. 3, $a-c$ ) and curved track sections with radius $500 \mathrm{~m}$ (Fig. 4, $a-c$ ) in the loaded mode.

The research results of the dynamic characteristics of open cars with new and worn wheels of the bogie models 18-9771, 18-9770 and 18-578 show that all the indicators are within the normative values and do not exceed the maximum permissible ones $[12,8]$. $a$

Values Cdu (straight)

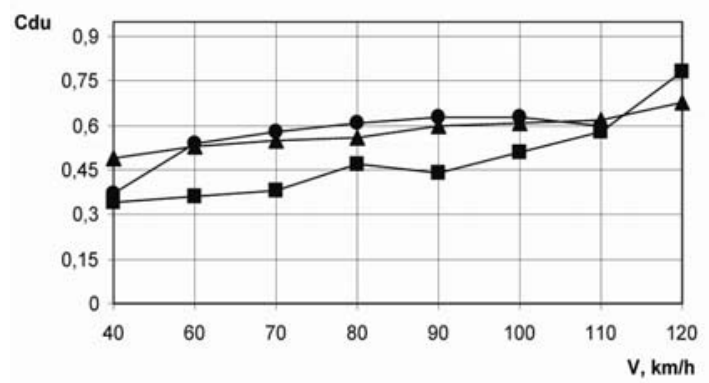

$b$
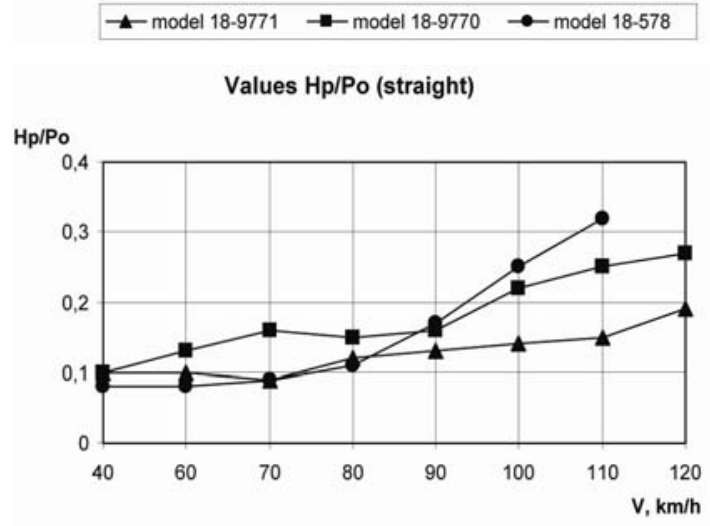

$\neg$ model 18-9771 $\rightarrow$ model 18-9770 $\rightarrow$ model 18-578

$c$

Values $\mathrm{Hp} / \mathrm{Po}$ (curve R=500 $\mathrm{m}$ )

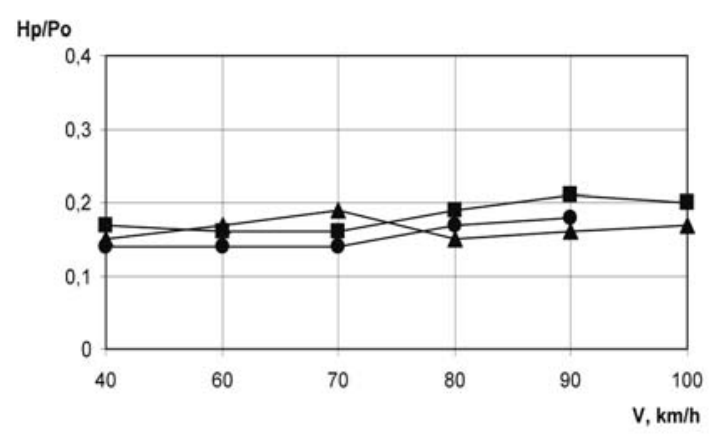

model 18-9771

model 18-9770

model 18-578

Fig. 2. Dependecy graphs of dynamic performance on the vaues of motion speed in empty mode: $a$-vertical dynamics coefficient of unsprung bogie frame $C$ du (straight); $b$ - ratio of the side frame force to the static axial loading $H \mathrm{p} / P$ o (straight) $c$-ratio of the side frame force to the atatic axial loading $H \mathrm{p} / P$ o (curve $R=500 \mathrm{~m}$ ) 


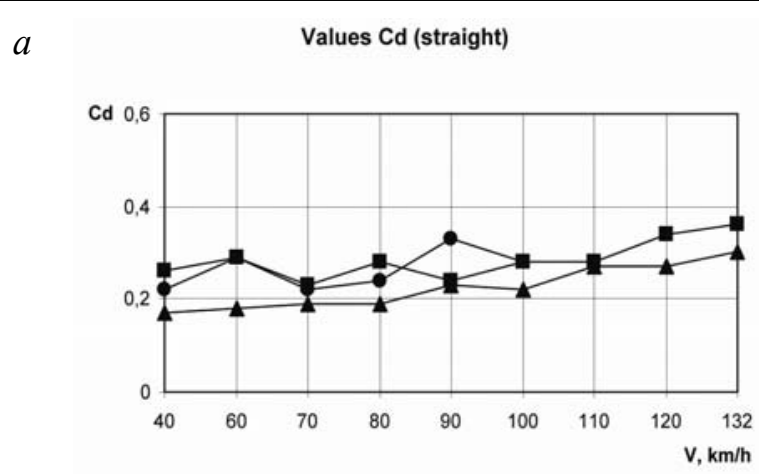

$\neg-$ model 18-9771 $\rightarrow$-model 18-9770 $\rightarrow$ model 18-578

$b$

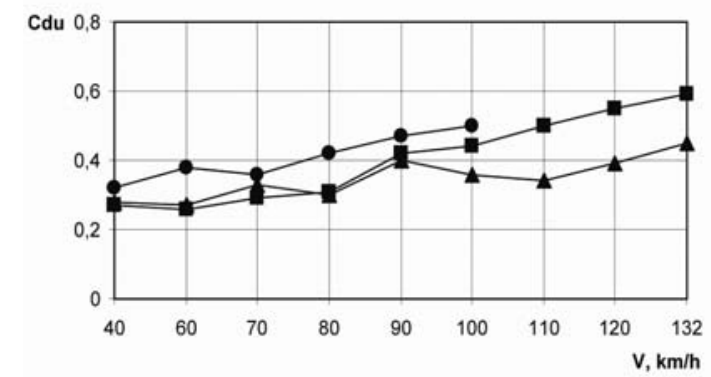

$c$

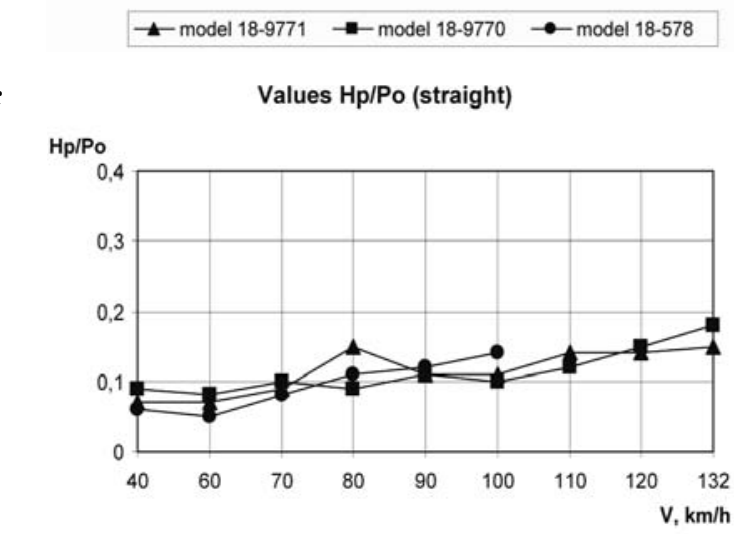

^-model 18-9771 $\rightarrow$-model 18-9770 $\rightarrow$ model 18-578

Fig. 3. Dependecy graphs of dynamic performance on the values of motion speed in the loaded mode on the straight track sections:

$a-$ vertical dynamics coefficient of the body frame $(C \mathrm{~d})$; $b$ - vertical dynamics coefficient of unsprung bogie frame $(C \mathrm{du}) ; c-$ ratio of the side frame force to the atatic axial loading $(H \mathrm{p} / \mathrm{Po})$ $a$

Values Cd (curve R=500 $\mathrm{M}$ )

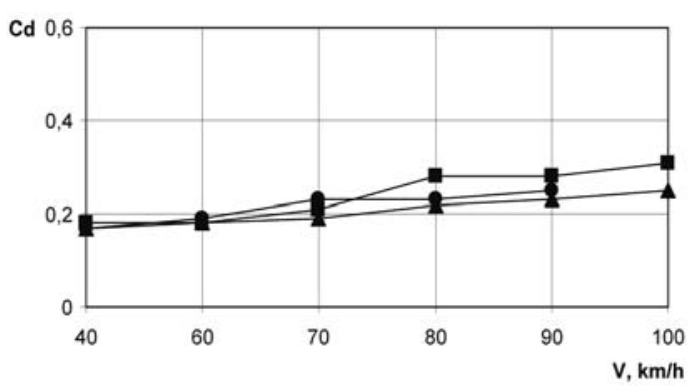

-model 18-9771 $\rightarrow-$ model 18-9770 $\rightarrow-$ model 18-578

$b$

Values Cdu (curve R=500 $\mathrm{M}$ )

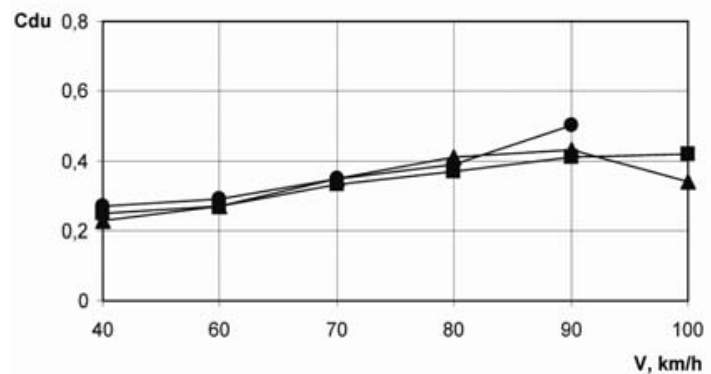

$c$

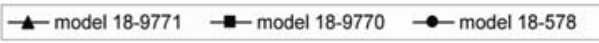

Values $\mathrm{Hp} / \mathrm{Po}$ (curve R=500 $\mathrm{M}$ )

HP/Po

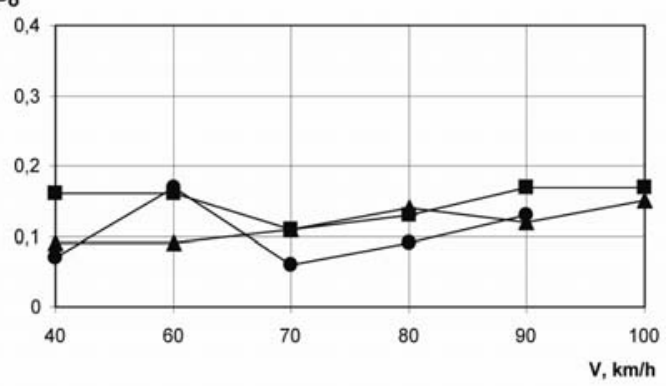

model 18-9771

model 18-9770

model $18-578$

Fig. 4. Graphs of dynamic values dependence on the traffic speed in loaded mode in curved track sections $(R=500 \mathrm{~m})$ :

$a$ - vertical dynamics coefficient of the body frame $(C \mathrm{~d})$; $b$ - vertical dynamics coefficient of unsprung bogie frame $(C \mathrm{du}) ; c$ - ratio of the side frame force to the atatic axial loading $(H \mathrm{p} / P \mathrm{o})$ 
Technical characteristics of the freight bogies

\begin{tabular}{|c|c|c|c|}
\hline \multirow{2}{*}{ Indicator } & \multicolumn{3}{|c|}{ Models of freight bogies } \\
\hline & $18-9771$ & $18-9770$ & $18-578$ \\
\hline Bogie weight, kg & 4900 & 4900 & 4750 \\
\hline Base, $\mathrm{m}$ & 1.85 & 1.85 & 1.85 \\
\hline Permisible speed, $\mathrm{km} / \mathrm{h}$ & 120 & 120 & 120 \\
\hline Flexibility of swing suspension, $\mathrm{m} / \mathrm{MN}$ & 0.130 & 0.125 & 0.130 \\
\hline Spring set deflection under the static loading, $\mathrm{m}$ & 0.068 & 0.049 & 0.068 \\
\hline $\begin{array}{l}\text { Distance from the rail head level to the bearing surface } \\
\text { of the centrer plate, } m\end{array}$ & 0.811 & 0.801 & 0.811 \\
\hline Type of swing suspesion & \multicolumn{3}{|c|}{ one stage central } \\
\hline
\end{tabular}

Table 2

Value of the stability coefficient

\begin{tabular}{|c|c|c|c|c|c|c|c|c|}
\hline \multirow{2}{*}{ Value } & \multicolumn{2}{|c|}{$18-9771$} & \multicolumn{2}{|c|}{$18-578$} & \multicolumn{2}{|c|}{$18-9770$} & \multicolumn{2}{|c|}{ Permissible values } \\
\hline & Empty & Loaded & Empty & Loaded & Empty & Loaded & Empty & Loaded \\
\hline $\begin{array}{l}\mathrm{K}_{\mathrm{yc}}-\text { is the derailment stability } \\
\text { coefficient } \mathrm{p}=0.01 \\
\mathrm{~K}_{\mathrm{ycn}}-\text { transverse stability coef- } \\
\text { ficient in curves: }\end{array}$ & 1.87 & 2.98 & 1.74 & 2.48 & $>3$ & $>3$ & \multicolumn{2}{|c|}{ Minimum 1.6} \\
\hline$-\mathrm{V}=100 \mathrm{~km} / \mathrm{h}, \mathrm{R}=500 \mathrm{~m}$ & 2.19 & 2.79 & 1.89 & $>3$ & 2.1 & 2.69 & \multicolumn{2}{|c|}{ Minimum 1.8} \\
\hline$-\mathrm{V}=10 \mathrm{~km} / \mathrm{h}, \mathrm{R}=350 \mathrm{~m}$ & $>3$ & $>3$ & $>3$ & $>3$ & $>3$ & $>3$ & \multicolumn{2}{|c|}{ Minimum 1.8} \\
\hline
\end{tabular}

Table 3

Value of the stability coefficient with $V=120 \mathrm{~km} / \mathrm{h}$

\begin{tabular}{l|c|c|c}
\hline \multirow{2}{*}{} & \multicolumn{3}{|c}{ Bogie Type } \\
\cline { 2 - 4 } & Model 18-9771 & Model 18-9770 & Model 18-578 \\
\hline $\mathrm{P}=0.0001$ & 2.3 & 2.15 & 2.25 \\
$\mathrm{P}=0.001$ & 2.53 & 2.3 & 2.54 \\
$\mathrm{P}=0.01$ & 2.98 & 2.48 & more than 3
\end{tabular}

For example, the analysis of the values of the of vertical dynamics coefficient of unsprung bogie frame $(C \mathrm{du})$ (Fig. 4, $a$ ), the ratio of the side frame force to the atatic axial loading $(H \mathrm{p} / \mathrm{Po})$ on the straight track section at design speed of $120 \mathrm{~km} / \mathrm{h}$ (Fig. 4, b) and in the curve $\mathrm{R}=500 \mathrm{~m}$ (Fig. 4, c) shows that the dynamic performance of the open cars with the new bogie is better than on the bogie models $18-578$ and 18-9770. This fact confirms that the constant contact bearers improve the running qualities of the freight cars, reducing the load- ings transmitted from the rolling stock on the railway track.

For clarity the values of the stability coefficient $(C \mathrm{~s})$ according to the results of dynamic tests are shown in Table 2 and 3.

Thus, the obtained results clearly demonstrate not only the opportunity to improve the structural scheme of the freight car bogies, but also the correctness of engineering solutions to improve the designs of freight car bogies. 


\section{Originality and practical value}

Severization of requirements to the technical specifications of the freight cars primarily concerns the running gears $[1,2,5,6]$. Therefore, the efforts of designers and scientists are focused on improving the parameters of freight car bogies $[3,17,18]$. At this the advanced engineering solutions and innovative design developments are used [20,21].

The development of freight car bogie on CJSC «Promtractor Vagon» can be an example for creation of innovative technology for railway transport.

When designing the bogie for loading $23.5 \mathrm{t} / \mathrm{axle}$ almost all available technical solutions to improve the characteristics of the freight car bogies: elastic bearers, cassette bearing in axle boxes, axle boxe adapter of original design, bilinear central spring suspension, etc. were used.

\section{LIST OF REFERENCE LINKS}

1. Вериго, М. Ф. Взаимодействие пути и подвижного состава / М. Ф. Вериго, А. Я. Коган. - М. : Транспорт, 1986. - 560 с.

2. Вершинский, С. В. Динамика вагона / С. В. Вершинский, В. Н. Данилов, В. Д. Хусидов. - М. : Транспорт, 1991. -360 с.

3. Динамика грузовых вагонов с учетом поперечного смещения тележек / Н. И. Луханин, С. В. Мямлин, Л. А. Недужая, А. А. Швец // Зб. наук. праць ДонІЗТ. - Донецьк, 2012. Вип. 29. - С. 234-241.

4. Ефимов, В. П. Технический уровень тележки 18-578 в сравнении с тележкой 18-100 / В. П. Ефимов // Ж.-д. трансп. - 2006. - № 7. C. 56-60.

5. Лазарян, В. А. Динамика вагонов / В. А. Лазарян. - М. : Транспорт, 1964. -256 с.

6. Лазарян, В. А. Динамика транспортных средств / В. А. Лазарян. - К. : Наук. думка, 1985. $-528 \mathrm{c}$.

7. Мямлин, С. В. Теоретические исследования динамики полувагонов / С. В. Мямлин, Л. А. Недужая, А. А. Тен // Зб. наук. пр. ДонІЗТ. - Донецьк, 2010. - Вип. 24. - С. 143-151.

8. Нормы для расчета и проектирования вагонов железных дорог МПС колеи 1520 мм (несамоходных) (с изменениями и дополнениями № 1 (с 01.02.2000 г.) и № 2 (с 01.03.2002 г.). - М. : ГосНИИВ. - ВНИИЖТ, 1996. - 352 с.

9. Оценка динамических качеств различных конструкций тележек грузовых вагонов / С. В. Мямлин, Л. А. Недужая, Е. А. Письменный, А. И. Яловой // Подвижной состав XXI века: идеи, требования, проекты. - СПб : ПГУПС, 2005. - С. 229-235.

10. Пат. 88627 Российская Федерация, МПК В61F 3/02. Тележка двухосная грузового вагона / Тен А. А. ; заявитель и патентообладатель ЗАО «Промтрактор-Вагон». - № 2009128488/22 ; заявл. 22.07.2009 ; опубл. 20.11.2009, Бюл. № 32. -3 с: ил. 1.

11. Промтрактор-вагон [Electronic resource]. - Access mode: www.promtractor-vagon.ru. - Title from the screen.

12. РД 24.050.37.95. Вагоны грузовые и пассажирские. Методы испытаний на прочность и ходовые качества. - Введ. 1995-02-02. - М. : ГосНИИВ, 1995. - $102 \mathrm{c}$.

13. Ромен, Ю. С. Результаты комплексных испытаний новых типов тележек грузовых вагонов / Ю. С. Ромен, А. В. Заверталюк, М. С. Тихов // Подвижной состав XXI века: идеи, требования, проекты. - СПб : ПГУПС, 2009. - С. 108-116.

14. УралВагонЗавод [Electronic resource]. - Access mode: www.uvz.ru. - Title from the screen.

15. Хабырин, И. А. Совершенствовать ходовую часть грузовых вагонов / И. А. Хабырин, А. М. Орлова, А. В. Додонов // Вагоны и вагон. хоз-во. - 2009. - № 2. - С. 26-29.

16. Шадур, Л. А. Вагоны. Конструкция, теория и расчет / Л. А. Шадур. - М. : Транспорт, 1980. $-440 \mathrm{c}$.

17. Bubnov, V. M. Dynamic performance of freight cars on bogies model 18-1711 / V. M. Bubnov, S. V. Myamlin, N. V. Mankevych // Наука та прогрес трансп. Вісн. Дніпропетр. нац. ун-ту залізн. трансп. - 2013. - № 4 (46).- С. 118-126.

18. Determination of Dynamic Performance of Freight Cars Taking into Account Technical Condition of Side Bearers / S. Myamlin, L. Neduzha, O. Ten, A. Shvets // Наука та прогрес трансп. Вісн. Дніпропетр. нац. ун-ту залізн. трансп. - 2013. № 1 (43). - 2013. - C. 162-169.

19. Myamlin, S. Mathematical Modeling of a Cargo Locomotive / S. Myamlin, S. Dailidka, L. Neduzha // Proc. of 16th Intern. Conf. «Transport Means». - Kaunas, 2012. - P. 310-312.

20. Research of Friction Indices Influence on the Freight Car Dynamics / S. Myamlin, L. Neduzha, O. Ten, A. Shvets // TEKA Commission of Motorization and Power Industry in Agriculture. Vol. 13, № 4. - 2013. - P. 159-166.

21. Spatial Vibration of Cargo Cars in Computer Modelling with the Account of Their Inertia Properties / S. Myamlin, A. Ten, L. Neduzha, A. Shvets // Proc. of 15th Intern. Conf. «Mechanika». - Kaunas, 2010. - P. 325-328. 


\section{С. В. МЯМЛИН ${ }^{1}$, А. А. ТЕН ${ }^{2}$ Л. А. НЕДУЖАЯ ${ }^{3 *}$}

${ }^{1}$ Каф. «Вагоны и вагонное хозяйство», Днепропетровский национальный университет железнодорожного транспорта имени академика В. Лазаряна, ул. Лазаряна, 2, Днепропетровск, Украина, 49010, тел./факс +38 (056) 7931903 , эл. почта sergeymyamlin@gmail.com, ORCID 0000-0002-7383-9304

${ }^{2}$ ЗАО «Промтрактор-Вагон», ул. Ильича, 1 а, Канаш, Чувашская Республика, Российская Федерация, 429332

${ }^{3 *}$ Каф. «Строительная механика», Днепропетровский национальный университет железнодорожного транспорта имени академика В. Лазаряна, ул. Лазаряна, 2, Днепропетровск, Украина, 49010, тел./факс +38 (056) 7931903 , эл. почта nlorhen@i.ua, ORCID 0000-0002-7038-3006

\section{ЭКСПЕРИМЕНТАЛЬНЫЕ ИССЛЕДОВАНИЯ ДИНАМИЧЕСКИХ КАЧЕСТВ ГРУЗОВЫХ ВАГОНОВ С ТЕЛЕЖКАМИ РАЗНЫХ КОНСТРУКЦИЙ}

Цель. С появлением новых конструкций грузовых вагонов особую важность приобретает задача, связанная с созданием более современных тележек, оценкой их динамических качеств в зависимости от типа и особенностей конструкции, с учетом осевых нагрузок, обеспечения динамических и ходовых качеств, соответствующих условиям по воздействию на путь, устойчивости, величине рамных сил и др. С целью постановки новой продукции на производство и для оценки динамических качеств с использованием различных конструкций тележек в работе необходимо провести ходовые испытания, которые позволят сравнить динамические показатели новой тележки с существующими моделями. Методика. Исследование проводилось методом численного интегрирования и математического моделирования динамической нагруженности грузового вагона с использованием программного комплекса «Dynamics of Rail Vehicles» («DYNRAIL»). Результаты. Приведены результаты исследований динамических характеристик полувагонов на новых и изношенных колесах тележек моделей 18-9771, 18-9770 и 18-578 в графической и табличной формах. Все показатели находятся в пределах нормативных значений и не превосходят максимально допустимых. Научная новизна. При создании тележки для нагрузок 23,5 т/ось использовались практически все имеющиеся технические решения по совершенствованию характеристик тележек грузовых вагонов: упругие скользуны, кассетные подшипники в буксовых узлах, буксовый адаптер оригинальной конструкции, билинейное центральное рессорное подвешивание и т.д. Практическая значимость. В результате выполненных инженерных работ по проектированию и изготовлению усовершенствованных конструкций тележек грузовых вагонов получена новая конструкция, которая не уступает по своим динамическим качествам лучшим аналогам. Выполненный выбор рациональных значений упруго-диссипативных параметров тележки позволяет создать типоразмерный ряд ходовых частей грузовых вагонов для перспективных условий эксплуатации. Полученные результаты имеют практическое значение, что нашло отображение в ряде публикаций авторов в специальных и научно-популярных изданиях.

Ключевые слова: грузовые вагоны; скользуны тележек; скорость движения; прямые и кривые участки пути; динамические показатели

\section{С. В. МЯМЛІН ${ }^{1}$, О. О. ТЕН ${ }^{2}$, Л. О. НЕДУЖА ${ }^{3 *}$}

\footnotetext{
${ }^{1}$ Каф. «Вагони та вагонне господарство», Дніпропетровський національний університет залізничного транспорту имені академіка В. Лазаряна, вул. Лазаряна, 2, Дніпропетровськ, Україна, 49010, тел./факс +38 (056) 7931903 , ел. пошта sergeymyamlin@gmail.com, ORCID 0000-0002-7383-9304

${ }^{2}$ ЗАТ «Промтрактор-Вагон», вул. Ілліча, 1 а, Чувашська Республіка, Канаш, Російська Федерація, 429332

${ }^{3 *}$ Каф. «Будівельна механіка», Дніпропетровський національний університет залізничного транспорту імені академіка В. Лазаряна, вул. Лазаряна, 2, Дніпропетровськ, Україна, 49010, тел./факс +38 (056) 79319 03, ел. пошта nlorhen@i.ua, ORCID 0000-0002-7038-3006
}

\section{ЕКСПЕРИМЕНТАЛЬНІ ДОСЛІДЖЕННЯ ДИНАМІЧНИХ ЯКОСТЕЙ ВАНТАЖНИХ ВАГОНІВ ІЗ ВІЗКАМИ РІЗНИХ КОНСТРУКЦІЙ}

Мета. 3 появою нових конструкцій вантажних вагонів особливо важливим є завдання, пов'язане зі створенням більш сучасних візків, оцінкою їх динамічних якостей у залежності від типу та особливостей конструкції, з урахуванням осьових навантажень, забезпечення динамічних і ходових якостей, що відповідають 
умовам із впливу на колію, стійкості, величині рамних сил та ін. 3 метою постановки нової продукції на виробництво й для оцінки динамічних якостей із використанням різних конструкцій візків у роботі необхідно провести ходові випробування, які дозволять порівняти динамічні показники нового візка з існуючими моделями. Методика. Дослідження проводилось методом чисельного інтегрування та математичного моделювання динамічної завантаженості вантажного вагону з використанням програмного комплексу «Dynamics of Rail Vehicles» («DYNRAIL»). Результати. Наведено результати досліджень динамічних характеристик піввагонів на нових і зношених колесах візків моделей 18-9771, 18-9770 та 18-578 у графічній і табличній формах. Всі показники знаходяться в межах нормативних значень і не перевищують максимально допустимих. Наукова новизна. При створенні візка для навантажень 23,5 т/вісь використовувалися практично всі наявні технічні рішення з удосконалення характеристик візків вантажних вагонів: пружні ковзуни, касетні підшипники в буксових вузлах, буксовий адаптер оригінальної конструкції, білінійне центральне ресорне підвішування і т.д. Практична значимість. За результатами виконаних інженерних робіт із проектування й виготовлення удосконалених конструкцій візків вантажних вагонів отримано нову конструкцію, яка не поступається за своїми динамічними якостями кращим аналогам. Виконаний вибір раціональних значень пружнодисипативних параметрів візків дозволяє створити типорозмірний ряд ходових частин вантажних вагонів для перспективних умов експлуатації. Отримані результати мають практичну значимість, що знайшло відображення в ряді публікацій авторів у спеціальних та науково-популярних виданнях

Ключові слова: вантажні вагони; ковзуни візків; швидкість руху; прямі та криві ділянки колії; динамічні показники

\section{REFERENCES}

1. Verigo M.F., Kogan A.Ya. Vzaimodeystviye puti i podvizhnogo sostava [Railway track and rolling stock interaction]. Moscow, Transport Publ., 1986. 560 p.

2. Vershinskiy S.V., Danilov V.N., Khusidov V.D. Dinamika vagona [Car dynamics]. Moscow, Transport Publ., 1991. 360 p.

3. Lukhanin N.I., Myamlin S.V., Neduzhaya L.A., Shvets A.A. Dinamika gruzovykh vagonov s uchetom poperechnogo smeshcheniya telezhek [Freight cars dynamics taking into account transversal displacement of the bogies]. Zbirnyk naukovykh prats Donetskoho instytutu zaliznychnoho transportu [Proc. of the Donetsk Railway Transport Institute], 2012, issue 29, pp. 234-241.

4. Yefimov V.P. Tekhnicheskiy uroven telezhki 18-578 v sravnenii s telezhkoy 18-100 [The technical level of the bogie 18-578 compared to 18-100 bogie]. Zheleznodorozhnyy transport-Railway Transport, 2006, no. 7, pp. 56-60.

5. Lazaryan V.A. Dinamika vagonov [Dynamics of cars]. Moscow, Transport Publ., 1964. 256 p.

6. Lazaryan V.A. Dinamika transportnykh sredstv [Dynamics of vehicles]. Kyiv, Naukova dumka, 1985.528 p.

7. Myamlin S.V., Neduzhaya L.A., Ten A.A. Teoreticheskiye issledovaniya dinamiki poluvagonov [Theoretical studies of the open car dynamics]. Zbirnyk naukovykh prats Donetskoho instytutu zaliznychnoho transportu [Proc. of the Donetsk Railway Transport Institute], 2010, issue 24, pp. 143-151.

8. Normy dlya rascheta i proyektirovaniya vagonov zheleznykh dorog MPS kolei $1520 \mathrm{~mm}$ (nesamokhodnykh) [Standards for calculation and construction of railroads with $1520 \mathrm{~mm}$ track cars (non-self-propelled)]. Moscow, GosNIIV-VNIIZhT Publ., 1996. 352 p.

9. Myamlin S.V., Neduzhaya L.A., Pismennyy Ye.A., Yalovoy A.I. Otsenka dinamicheskikh kachestv razlichnykh konstruktsiy telezhek gruzovykh vagonov [Evaluation of dynamic qualities of different designs of freight car bogies]. Podvizhnoy sostav XXI veka: idei, trebovaniya, proyekty [Rolling stock of XXI century: ideas, requirements, projects], Saint Petersburg, 2005, pp. 229-235.

10. Ten A.A. Telezhka dvukhosnaya gruzovogo vagona [Two-axle bogie of a freight car]. Pat. RF, no. 2009128488/22. 3 p.

11. Promtraktorvagon (Promtractor-Vagon). Available at: www.promtractor-vagon.ru (Accessed 5 February, 2014).

12. RD 24.050.37.5. Vagony gruzovyye i passazhirskiye. Metody ispytaniy na prochnost $i$ khodovyye kachestva [RD 24.050.37.95. Freight and passenger cars. Methods of testing for strength and running characteristics]. Moscow, GosNIIV Publ., 1995. 102 p.

13. Romen Yu.S., Zavertalyuk A.V, Tikhov M.S. Rezultaty kompleksnykh ispytaniy novykh tipov telezhek gruzovykh vagonov [Results of comprehensive tests of new types of freight car bogies]. Podvizhnoy sostav XXI veka: idei, trebovaniya, proyekty [Rolling stock of XXI century: ideas, requirements, projects], Saint Petersburg, PGUPS Publ., 2009, pp. 108-116. 
14. UralVagonZavod (Ural Vagon Plant). Available at: www.uvz.ru. (Accessed 5 February, 2014).

15. Khabyrin I.A., Orlova A.M., Dodonov A.V. Sovershenstvovat khodovuyu chast gruzovykh vagonov [To improve the running gears of freight cars]. Vagony $i$ vagonnoye khozyaystvo - Cars and rolling stock, 2009, issue 2, pp. 26-29.

16. Shadur L.A. Vagony: Konstruktsiya, teoriya i raschet [Cars: Construction, theory and calculation]. Moscow, Transport Publ., 1980. 440 p.

17. Bubnov V.M., Myamlin S.V., Mankevych N.V. Dynamic performance of freight cars on bogies model 18-1711. Visnyk Dnipropetrovskoho natsionalnoho universitetu zaliznychnoho transportu imeni akademika V. Lazariana [Bulletin of Dnipropetrovsk National University of Railway Transport named after Academician V. Lazaryan], 2013, issue 4 (46), pp. 118-126.

18. Myamlin S., Neduzha L., Ten O., Shvets A. Determination of Dynamic Performance of Freight Cars Taking Into Account Technical Condition of Side Bearers. Visnyk Dnipropetrovskoho natsionalnoho universitetu zaliznychnoho transportu imeni akademika V. Lazariana [Bulletin of Dnipropetrovsk National University of Railway Transport named after Academician V. Lazaryan], 2013, issue 1 (43), pp. 162-169.

19. Myamlin, S., Dailidka S., Neduzha L. Mathematical Modeling of a Cargo Locomotive. Proc. of $16^{\text {th }}$ Intern. Conf. «Transport Means»]. Kaunas, 2012, pp. 310-312.

20. Myamlin S., Neduzha L., Ten O., Shvets A. Research of Friction Indices Influence on the Freight Car Dynamics. TEKA Commission of Motorization and Power Industry in Agriculture, vol. 13, no. 4, 2013, pp. 159-166.

21. Myamlin S., Neduzha L., Ten O., Shvets A. Spatial Vibration of Cargo Cars in Computer Modelling with the Account of Their Inertia Properties. Proc. of 15th Intern. Conf. «Mechanika». Kaunas, 2010, pp. 325-328.

Prof. V. L. Horobets, D. Sc. (Tech.); Prof. M. O. Radchenko, D. Sc. (Tech.) recommended this article to be published

Received: Feb. 20, 2014

Accepted: April 14, 2014 